\title{
Quantifying phytate in dairy digesta and feces: Alkaline extraction and high-performance ion chromatography ${ }^{1}$
}

\author{
P. P. Ray, ${ }^{\star}$ C. Shang, † R. O. Maguire, $†$ and K. F. Knowlton ${ }^{2}$ \\ *Department of Dairy Science, and \\ †Department of Crop and Soil Environmental Sciences, Virginia Polytechnic Institute and State University, Blacksburg 24061
}

\begin{abstract}
Development of an analytical method with appropriate combination of extraction and quantification approaches for undigested phytate in ruminant feces and digesta will advance knowledge of phytate degradation in ruminants and help to reduce phosphorus excretion. Established quantification methods give satisfactory results for feedstuffs and nonruminant manure but recovery of phytate is incomplete for ruminant feces and digesta because of their complex sample matrix and low ratio of phytate to inorganic $\mathrm{P}$. The objective was to develop a robust, accurate, sensitive, and inexpensive method to extract and quantify phytate in feeds, ruminant feces, and digesta. Diets varying in phytate content were fed to dairy heifers, dry cows, and lactating cows to generate digesta and fecal samples of varying composition to challenge extraction and quantification methods. Samples were extracted with $0.5 M \mathrm{HCl}$ or $0.25 M \mathrm{NaOH}+0.05 M$ EDTA. Acid extracts were mixed with $20 \% \mathrm{NaCl}$, alkaline extracts were acidified to final $\mathrm{pH}<2$, and then both extracts were clarified with $\mathrm{C}_{18}$ cartridges and $0.2-\mu \mathrm{m}$ filters. High-performance ion chromatography (HPIC) was used to quantify phytate. In feed samples, the measured phytate was comparable in alkaline and acid extracts $(2,965$ vs. $3,085 \mu \mathrm{g} / \mathrm{g}$ of DM). In digesta and fecal samples, alkaline extraction yielded greater estimates of phytate content than did acid extraction (40.7 vs. 33.6 and 202.9 vs. $144.4 \mu \mathrm{g} / \mathrm{g}$ of DM for digesta and fecal samples, respectively). Analysis of alkaline extracts by HPIC is usually not possible because of sample matrix interferences; acidification and $\mathrm{C}_{18}$-cartridge elution of alkaline extracts prevented this interference. Pure phytate added to dry samples before extraction was almost
\end{abstract}

\footnotetext{
Received September 27, 2011.

Accepted January 31, 2012.

${ }^{1}$ This project was supported by National Research Initiative Competitive Grant no. 2009-55206-05267 from the USDA Cooperative State Research, Education, and Extension Service (Washington, DC). Author Ray received fellowship support from the John Lee Pratt Foundation (Blacksburg, VA).

${ }^{2}$ Corresponding author: knowlton@vt.edu
}

completely recovered ( 88 to $105 \%$ ), indicating high extraction efficiency, no adverse effect of extract cleanup procedures, and accurate quantification of phytate. The proposed method is rapid, inexpensive, robust, and combines the extraction power of $\mathrm{NaOH}-\mathrm{EDTA}$ with the precision and sensitivity of HPIC quantification, allowing accurate quantification of phytate in feeds, ruminant digesta, and fecal samples.

Key words: high-performance ion chromatography, dairy feces, phytate

\section{INTRODUCTION}

The quantification of phytate in feed, digesta, and feces from dairy cows is important in nutritional and environmental research. Environmental pollution due to $\mathrm{P}$ runoff from livestock farms is a growing global concern, leading to efforts to develop and implement nutritional strategies to minimize the $\mathrm{P}$ excretion without impairing production (Knowlton et al., 2004; VandeHaar and St-Pierre, 2006). Improved understanding of the fate of dietary $\mathrm{P}$ in the digestive tract may support improved P utilization by livestock to decrease their environmental impact.

One challenge limiting application of dietary P management is variation in $\mathrm{P}$ availability or digestibility in feedstuffs (Bravo et al., 2003; Mjoun et al., 2008; Cherry et al., 2010). Phytate is the major form of $\mathrm{P}$ in grains and many byproduct feed ingredients (Eeckhout and De Paepe, 1994; Ravindran et al., 1994). Ruminants can utilize phytate-P because ruminal microorganisms express the enzyme phytase, which hydrolyzes phytate into simpler organic forms of $\mathrm{P}$ or inorganic $\mathrm{P}$. Because it is the major form of $\mathrm{P}$ in the concentrate portion of dairy rations, however, incomplete hydrolysis of phytate in the rumen may limit $\mathrm{P}$ availability. Although a body of research from previous decades documents complete hydrolysis of phytate in the rumen of lactating cows (Nelson et al., 1976; Clark et al., 1986; Morse et al., 1992), high-producing dairy cows consume more DM and their diets contain less forage as compared with the animals used in early studies (Phipps et al., 2000). The resulting higher dietary phytate intake and higher 
passage rate of digesta due to high DMI may result in incomplete degradation of phytate $\mathrm{P}$ in the rumen. Other factors that have been shown to cause variation in the hydrolysis of phytate in the rumen are the type of grain, processing of feedstuffs, and supplementation with exogenous enzymes (Park et al., 1999; Bravo et al., 2003; Kincaid et al., 2005).

In interpreting earlier work on phytate digestion by ruminants, limitations in methods used to quantify phytate $\mathrm{P}$ in feces must also be considered. Classical methods are based on the precipitation of phytate as an insoluble iron-phytate complex but these methods are too insensitive for low phytate samples (Wheeler and Ferrel, 1971). Also, the complexity of feces with its undigested feed residues, partially digested microbial residues, and endogenous cellular material challenges traditional methods of phytate quantification. Within this matrix, phytate is complexed with minerals and other nutrients. If recovery of fecal phytate is incomplete due to methodological limitations, fecal phytate may be underestimated in these earlier studies.

The initial step for the quantification of phytate $\mathrm{P}$ is the extraction of that form of $\mathrm{P}$ from the sample. Quantitative extraction of phytate from digesta and feces is more difficult than from feed because this phytate is always bound with cations, protein, or other nutrients to a greater extent than it is in feed and in monogastric manure samples, leading to erroneous estimation or damage to the analytical instruments, or both. Factors affecting recovery of P-containing compounds in different extraction schemes include type of extractant, sample matrix, and sample handling. Of 2 commonly used extractants, $\mathrm{HCl}$ gives satisfactory recovery of total and phytate $\mathrm{P}$ in feed and monogastric digesta and feces (Skoglund et al., 1997; Leytem et al., 2008 ) but recovery of $\mathrm{P}$ is poor in the complex matrix of ruminant feces (McDowell et al., 2008). Alkaline extraction, most commonly with $0.25 \mathrm{M} \mathrm{NaOH}+0.05$ $M$ EDTA, gives almost complete recovery of total and various forms of $\mathrm{P}$ in feed and fecal samples (Turner, 2004; Toor et al., 2005; McDowell et al., 2008) but is incompatible with the high-performance ion chromatography (HPIC) quantification method because the alkaline extract causes column damage and interference from the matrix of the extracted sample. Thus, phytate in alkaline extracts is quantified using nuclear magnetic resonance $\left({ }^{31} \mathbf{P} \mathbf{N M R}\right)$, but this method has shortcomings, including long analysis time, relatively high cost, and insensitivity to low-phytate samples such as ruminant feces. High performance ion chromatography is compatible with acid extraction but recovery of total and phytate $\mathrm{P}$ from ruminant feces is not complete.
Development of robust, inexpensive, and reproducible techniques for accurate quantification of undigested phytate in complex animal manure and digesta samples is essential to advance knowledge of the effects of diet on phytate and $\mathrm{P}$ excretion in ruminants (Turner et al., 2002). Consequently, the objectives were to identify and evaluate an extraction method that adequately recovers phytate from feed, ruminant digesta, and fecal samples and is fully compatible with HPIC quantification.

\section{MATERIALS AND METHODS}

\section{Sample Collection}

For this method development project, dairy heifers ( $\mathrm{n}=2)$ and cows ( $\mathrm{n}=2$ dry and 2 lactating) were fed 2 or 3 different diets in sequential periods. Diets were designed to generate coordinated feed, digesta, and fecal samples of widely varying composition to challenge extraction and quantification methods. The experiment was carried out according to procedures approved by the Virginia Tech Animal Care and Use Committee.

Animals were fed experimental diets (Table 1) in 10-d periods; $7 \mathrm{~d}$ of diet adaptation and $3 \mathrm{~d}$ for sample collection. On d 8 to 10, fecal grab samples were collected twice daily, pooled by diet, and frozen $\left(-20^{\circ} \mathrm{C}\right)$. Lactating and dry cows were ruminally cannulated, allowing simultaneous collection of omasal samples using a vacuum pump (Huhtanen et al., 1997). Total mixed rations, concentrate mixes, and individual grain and forage samples were collected once per period and stored frozen $\left(-20^{\circ} \mathrm{C}\right)$. The diet sequence was fixed and diets were specific to a class of animals (heifers, dry cows, or lactating cows) because the focus was on generating a diverse sample set rather than evaluating the effect of animal, period, or diet.

\section{Sample Preparation and Conventional Analysis}

All samples were oven dried at $55^{\circ} \mathrm{C}$ to constant weight and ground with a Wiley mill (1-mm screen; Arthur H. Thomas Co., Philadelphia, PA). Dried samples were analyzed in duplicate for NDF, ADF, and ADL (Van Soest et al., 1991), starch (Hall, 2009), total Kjeldahl N, Ca, P, Mg, Al, Fe, and K (AOAC, 1984). Fiber analysis was sequential and NDF was quantified using amylase and sodium sulfite. Samples were ground further through a $0.2-\mathrm{mm}$ sieve (Z Grinder; ZM 100 USA, Retsch, Haan, Germany) and stored in air-tight containers for further analysis. A subset of fecal samples was thawed at room temperature $\left(20^{\circ} \mathrm{C}\right)$ and extracted wet (described below). 
Table 1. Ingredient composition of experimental diets

\begin{tabular}{|c|c|c|c|c|c|c|c|}
\hline $\begin{array}{l}\text { Ingredient } \\
\text { (\% of DM) }\end{array}$ & Mixed ration 1 & Mixed ration 2 & Mixed ration 3 & Mixed ration 4 & Mixed ration 5 & Mixed ration $6^{1}$ & Hay \\
\hline Grass hay & - & 9.03 & - & 71.3 & 71.3 & 64.0 & 100 \\
\hline Alfalfa silage & 9.24 & - & 11.6 & - & - & - & - \\
\hline Corn silage & 35.9 & 27.3 & 48.2 & 8.83 & 8.67 & 21.6 & - \\
\hline Barley straw & - & - & 1.89 & - & - & - & - \\
\hline Grain mix $4^{5}$ & - & - & - & 19.9 & - & - & - \\
\hline Grain mix $5^{6}$ & - & - & - & - & 20.0 & - & - \\
\hline Grain mix $6^{7}$ & - & - & - & - & - & 14.4 & - \\
\hline
\end{tabular}

\footnotetext{
${ }^{1}$ Dry cows were pen fed, and reported proportions of dietary ingredients are approximate.

${ }^{2}$ Grain mix 1 contained $60.3 \%$ corn, $28.0 \%$ soybean meal, $3.66 \%$ soybean hulls, $4.33 \%$ tallow, $1.67 \%$ limestone, $1.00 \%$ sodium bicarbonate, $0.33 \%$ salt, $0.33 \%$ urea, $0.17 \%$ potassium magnesium sulfate, $0.13 \%$ monoammonium phosphate, $0.04 \%$ Se, $0.03 \%$ mineral premix, $0.03 \%$ vitamin ADE, and $0.01 \%$ vitamin E.

${ }^{3}$ Grain mix 2 contained $64.4 \%$ corn, $33.1 \%$ cottonseed meal, $1.81 \%$ limestone, $0.50 \%$ trace mineral mix, and $0.16 \%$ vitamin ADE.

${ }^{4}$ Grain mix 3 contained $13.27 \%$ cottonseed meal, $13.27 \%$ soybean meal, $11.75 \%$ corn distillers whiskey (dehydrated), $7.5 \%$ corn, $15.33 \%$ hominy, $15.16 \%$ wheat middlings, $11.63 \%$ citrus pulp (dehydrated), $2.07 \%$ Megalac Plus (Church \& Dwight Co. Inc., Princeton, NJ), $1.60 \%$ cane molasses (dehydrated), $0.63 \%$ tallow, $2.11 \%$ limestone, 2.33\% Pro-Lak (H. J. Baker \& Bro. Inc., Westport, CT), $0.42 \%$ urea, $0.63 \%$ salt, $0.42 \%$ magnesium oxide, $0.42 \%$ potassium magnesium sulfate, $1.26 \%$ sodium bicarbonate, $0.07 \%$ Se (600), $0.06 \%$ trace mineral premix, $0.04 \%$ vitamin ADE, and $0.04 \%$ vitamin A.

${ }^{5}$ Grain mix 4 contained $50.25 \%$ corn, $49.3 \%$ soybean meal, $0.35 \%$ trace mineral mix, and $0.10 \%$ vitamin ADE.

${ }^{6}$ Grain mix 5 contained $61.64 \%$ corn, $37.91 \%$ cottonseed meal, $0.35 \%$ trace mineral mix, and $0.10 \%$ vitamin ADE.

${ }^{7}$ Grain mix 6 contained $39.9 \%$ corn, $29.9 \%$ soybean meal, $12.5 \%$ soybean hulls, $11.5 \%$ wheat middlings, $3.03 \%$ limestone, $1.00 \%$ salt, $0.50 \%$ magnesium oxide, $0.50 \%$ magnesium sulfate, $0.28 \%$ Se $(0.06 \%), 0.13 \%$ trace mineral premix, $0.13 \%$ vitamin ADE, and $0.27 \%$ vitamin E.
}

\section{Extraction, Extract Clean Up, and Phytate Analysis}

Chemical Extraction. Samples were subjected to 1 of 4 extraction protocols: $0.5 \mathrm{M} \mathrm{HCl}, 1 \mathrm{M} \mathrm{HCl}, 0.25$ $M$ NaOH-0.05 $M$ EDTA, and sequential extraction (0.5 $M \mathrm{HCl}$ extraction, followed by $0.25 M \mathrm{NaOH}-0.05 M$ EDTA extraction). For the extraction of dry samples, $1 \mathrm{~g}$ of dried ground sample was shaken with $20 \mathrm{~mL}$ of extractant on a horizontal shaker continuously for $4 \mathrm{~h}$ at room temperature. Then, samples were centrifuged at $30,000 \times g$ for $15 \mathrm{~min}$ at $4^{\circ} \mathrm{C}$ and supernatants decanted into acid-washed vials. Samples were extracted in triplicate, and for each replicate extract, duplicate 5 -mL aliquots of supernatant were analyzed for total $\mathrm{P}$ (AOAC, 1984). The $0.5 \mathrm{M} \mathrm{HCl}$ and $0.25 \mathrm{M} \mathrm{NaOH}-$ $0.05 M$ EDTA extracted P more efficiently than did the other 2 extraction methods, and these 2 were used for further experimentation focused on phytate quantification by HPIC.

Clean Up of Acid Extracts. Acidified extracts were categorized by sample matrix (high protein and starch feed samples vs. high fiber fecal and digesta samples) to determine the appropriate clean-up procedure. To remove proteins and starch, grain and TMR sample extracts were mixed 1:1 with a $20 \%$ (wt/vol) $\mathrm{NaCl}$ solution and stored overnight at $4^{\circ} \mathrm{C}$. Salt-treated extracts were centrifuged at $30,000 \times g$ for $20 \mathrm{~min}$ at $4^{\circ} \mathrm{C}$ and the supernatant was decanted into acid-washed vials. After centrifugation of salt-treated extracts, clear supernatants were diluted with deionized distilled water at 1:5 to bring the phytate concentration within the detection limit of the HPIC, and passed through a 0.2$\mu \mathrm{m}$ ion chromatography (IC) membrane (filter) into Dionex sample vials (Dionex Corp., Sunnyvale, CA) for HPIC analysis.

Forage, omasal, and fecal sample extracts, neither salt treated nor diluted, were centrifuged at $30,000 \times$ $g$ for 20 min at $4^{\circ} \mathrm{C}$ and supernatant was decanted into acid-washed vials. After centrifugation, clear supernatants were passed through a methanol-conditioned $\mathrm{C}_{18}$ cartridge (Waters Corp., Milford, MA) and then through a $0.2-\mu \mathrm{m}$ IC membrane (filter) into Dionex sample vials, discarding the first $2 \mathrm{~mL}$ of supernatant. The $\mathrm{C}_{18}$ cartridge has a hydrophobic silica-based binding phase capable of adsorbing analytes even with poor hydrophobicity from solutions.

Clean Up of Alkaline Extracts. Alkaline extracts were again categorized by sample matrix (high-protein and -starch feed samples vs. high-fiber fecal and digesta samples) to determine the appropriate clean-up procedure. Alkaline extracts of grain and TMR samples were acidified with $\mathrm{HCl}-\mathrm{HF}$ acid solution $(6 \mathrm{M} \mathrm{HCl}$ and $1.2 M \mathrm{HF}$ ) by adding $500 \mu \mathrm{L}$ of $\mathrm{HCl}-\mathrm{HF}$ acid solution to $5 \mathrm{~mL}$ of sample extract. Acidified extracts 
were stored overnight at $4^{\circ} \mathrm{C}$ and then centrifuged at $30,000 \times g$ for $20 \mathrm{~min}$ at $4^{\circ} \mathrm{C}$. After centrifugation of acidified extracts, clear supernatants were collected and diluted with deionized distilled water at 1:5 to bring the phytate concentration within the detection limit of the HPIC. The diluted extracts were then passed through a methanol-conditioned $\mathrm{C}_{18}$ cartridge before passing through a $0.2-\mu \mathrm{m}$ IC membrane (filter) into Dionex sample vials for IC analysis. The first $2 \mathrm{~mL}$ of supernatant were discarded.

Forage, omasal, and fecal sample extracts were acidified with the $\mathrm{HCl}-\mathrm{HF}$ acid solution as above and then centrifuged at $30,000 \times g$ for $20 \mathrm{~min}$ at $4^{\circ} \mathrm{C}$; supernatant was decanted into acid-washed vials. Supernatants of each sample were passed through a methanol-conditioned $\mathrm{C}_{18}$ cartridge (Waters Corp.) and then through a $0.2-\mu \mathrm{m}$ IC membrane (filter) into Dionex sample vials, discarding the first $2 \mathrm{~mL}$ of supernatant.

Spike Recovery. To evaluate extraction efficiency and accuracy of IC analysis, spike recovery tests were performed on selected low-phytate samples. Dried ground forage and omasal samples $(1 \mathrm{~g}$ of DM in triplicate) were spiked using $1 \mathrm{~mL}$ of phytate solution (100 $\mu \mathrm{g}$ of phytate- $\mathrm{P} / \mathrm{mL}$ ), whereas fecal samples (higher in phytate than forage and omasal samples) were spiked using $1 \mathrm{~mL}$ of higher-concentration phytate solution (300 $\mu \mathrm{g}$ of phytate-P/mL). Spiked samples were subjected to the same extraction, extract clean up, and analysis protocols described above. Samples were allowed to sit for $1 \mathrm{~h}$ after spike addition to improve the assimilation of spiking solution into the sample matrix.

HPIC Analysis. Chromatographic quantification of phytate in pretreated samples was achieved by HPIC (Dionex ICS 3000 with an HPLC pump, a Dionex $4 \times$ $50 \mathrm{~mm}$ IonPac AG7 guard column, and a $4 \times 250 \mathrm{~mm}$ IonPac AS7 analytical column; Dionex Corp.) using postcolumn reaction detection. Treated sample extracts were injected and phytate (inositol hexaphosphate) was eluted at $7.2 \mathrm{~min}$ with isocratic elution $(0.25 \mathrm{M}$ $\mathrm{HNO}_{3}$ ) at a flow rate of $1 \mathrm{~mL} / \mathrm{min}$. Eluted phytate was mixed with $0.1 \% \mathrm{Fe}\left(\mathrm{NO}_{3}\right)_{3}$ in $2 \% \mathrm{HClO}_{4}$ solution in a postcolumn reactor. The phytate products were measured at $290 \mathrm{~nm}$ on a UV-visible (UV-VIS) detector. Calibration standards $(3,15$, and $30 \mu \mathrm{g}$ of $\mathrm{P} / \mathrm{mL})$ were prepared from phytic acid, sodium salt hydrate (Sigma, St. Louis, MO).

\section{Statistical Analysis}

Total P extraction efficiency data were analyzed using PROC GLIMMIX of SAS (SAS Institute, 2002). The model included extractant, sample type, and their interaction as fixed effects. The model evaluating the effect of feces drying on total $\mathrm{P}$ extraction efficiency of different extractants included extractant, physical property, and their interaction as fixed effects. Significance was declared at $P<0.05$.

\section{RESULTS AND DISCUSSION}

\section{Sample Properties}

As intended, selected samples varied widely in their protein, starch, and fiber content (Tables 2 and 3). Feed CP content varied from 7.8 to $54.8 \%$, with standard deviation of $18.6 \%$. The variability in starch content of feed samples was $\pm 19.9 \%$ standard deviations. The fiber and lignin content of feed samples also varied between classes with high standard deviation. Within class, the variability in sample properties was less in omasal and fecal samples in comparison with the feed samples. Sample CP and starch composition may influence efficiency of different extractants for total $\mathrm{P}$ or phytate because phytate forms stable complexes with protein and starch (Fontaine et al., 1946; Bourdillon, 1951). Furthermore, in plant feed sources, the distribution of phytate varies with the type of plant and with the proportion of other nutrients (Lin et al., 2005). Therefore, different extractants may be needed for different sample types and also for samples within a type that vary in composition.

Content of mineral elements varied widely among sample types (feed, omasal contents, and feces) as well as within sample type (Tables 2 and 3). Among the major elements, $\mathrm{K}$ concentration was the highest, followed by $\mathrm{Ca}$ and $\mathrm{Mg}$, in feed and omasal samples; Ca was predominant in fecal samples. Among trace elements, $\mathrm{Al}$ and $\mathrm{Fe}$ were higher in omasal and fecal samples than in feed samples. He et al. (2009) suggested that the appropriate extractants for $\mathrm{P}$ depends on sample characteristics, including the association of $\mathrm{P}$ with $\mathrm{Ca}, \mathrm{Al}$, or Fe because adverse effects of these on the solubility of $\mathrm{P}$ or on $\mathrm{P}$ extraction efficiency have been reported for a variety of extractants (McDowell and Stewart, 2005; McDowell et al., 2008; He et al., 2009). McDowell and Stewart (2005) reported that $\mathrm{Al}$ and $\mathrm{Fe}$ were the major cations having an adverse effect on $\mathrm{P}$ solubility in dairy cattle feces, but in another study, McDowell et al. (2008) reported $\mathrm{Ca}$ as the major cation affecting total $\mathrm{P}$ extraction in feces of dairy cattle. Ajiboye et al. (2007) reported $\mathrm{Ca}$ as the most prevalent cation regulating $\mathrm{P}$ solubility in biosolids and hog, dairy, beef, and poultry manure.

Total $\mathrm{P}$ concentration in dried samples varied widely within sample type and across sample class (Table 4). The variability in total $\mathrm{P}$ concentration of fecal and omasal samples can be attributed to combined effects of variation in feed ingredients, individual animal varia- 
Table 2. Nutrient content of feed samples

\begin{tabular}{|c|c|c|c|c|c|c|c|c|c|c|}
\hline \multirow[b]{2}{*}{ Sample } & \multicolumn{8}{|c|}{ Nutrient (\% of DM) } & \multicolumn{2}{|c|}{$\begin{array}{c}\text { Nutrient } \\
(\mathrm{mg} / \mathrm{kg} \text { of } \mathrm{DM})\end{array}$} \\
\hline & $\mathrm{CP}$ & Starch & NDF & $\mathrm{ADF}$ & $\mathrm{ADL}$ & $\mathrm{Ca}$ & $\mathrm{K}$ & $\mathrm{Mg}$ & $\mathrm{Al}$ & $\mathrm{Fe}$ \\
\hline Soybean meal sample 1 & 52.1 & 7.6 & 21.6 & 6.34 & 3.01 & 0.35 & 2.59 & 0.31 & 545 & 230 \\
\hline Soybean meal sample 2 & 54.8 & 7.1 & 39.3 & 6.98 & 0.59 & 0.47 & 2.59 & 0.36 & 37 & 120 \\
\hline Soybean meal sample 3 & 50.7 & 6.9 & 29.8 & 8.73 & 1.58 & 0.43 & 2.51 & 0.37 & 752 & 564 \\
\hline Grain mix 6 & 19.1 & 36.1 & 31.4 & 15.5 & 2.09 & 1.49 & 1.17 & 0.70 & 255 & 495 \\
\hline \multicolumn{11}{|l|}{ Forage } \\
\hline Alfalfa hay & 17.4 & 1.1 & 54.9 & 40.9 & 14.0 & 1.07 & 2.30 & 0.27 & 592 & 763 \\
\hline Grass hay & 10.8 & 1.7 & 70.5 & 41.4 & 7.74 & 0.40 & 2.64 & 0.19 & 363 & 366 \\
\hline Corn silage sample 1 & 7.8 & 33.6 & 42.4 & 22.1 & 1.13 & 0.26 & 1.32 & 0.22 & 29 & 163 \\
\hline Corn silage sample 2 & 8.2 & 38.9 & 36.4 & 19.1 & 1.95 & 0.19 & 1.14 & 0.15 & 51 & 142 \\
\hline
\end{tabular}

tion in digestion, and $\mathrm{P}$ utilization efficiency related to the production stage of animals. In feed samples, total $\mathrm{P}$ concentration ranged from 1.6 to $14.8(\mathrm{SD}=3.6)$ $\mathrm{mg} / \mathrm{g}$ of DM. Commonly used feed ingredients contain total $\mathrm{P}$ ranging from 2.3 to $11.6 \mathrm{mg} / \mathrm{g}$ of $\mathrm{DM}$ (NRC, 2001). Total $P$ concentration in feces ranged from 5.6 to $12.0 \mathrm{mg} / \mathrm{g}$ of DM (Table 4), similar to values reported in the literature ( 4.6 to $14 \mathrm{mg} / \mathrm{g}$ of DM; Dou et al., 2003; Ajiboye et al., 2007; McDowell et al., 2008). Total $\mathrm{P}$ concentration in omasal samples was higher than in feed and feces (12.9 to $21.6 \mathrm{mg} / \mathrm{g}$ of $\mathrm{DM}$ ) because of the incorporation of inorganic $\mathrm{P}$ into the flow of $\mathrm{P}$ from the rumen through the release of recycled salivary $\mathrm{P}$ into the rumen (Valk et al., 2002; Puggaard et al., 2011).
Also, absorption of organic compounds, such as VFA from the rumen, concentrated $\mathrm{P}$ in the omasal contents.

\section{Efficiency of Extraction of Total P}

The efficiency of total $\mathrm{P}$ extraction from dried samples varied with extractant, sample type, and the interaction of extractant and sample type (Table 5). Alkaline extraction (NaOH-EDTA) was highly effective in extracting $\mathrm{P}$ from all sample types, and the extraction efficiency was generally lower with $0.5 \mathrm{M} \mathrm{HCl}$ than with other extractants (Table 5). The $\mathrm{P}$ in omasal contents (largely inorganic) was efficiently extracted by all extractants. The most commonly used acid and alkaline

Table 3. Nutrient content of digesta and feces samples

\begin{tabular}{|c|c|c|c|c|c|c|c|c|c|c|c|}
\hline \multirow[b]{2}{*}{ Sample type } & \multirow[b]{2}{*}{$\operatorname{Diet}^{1}$} & \multicolumn{8}{|c|}{ Nutrient ( $\%$ of DM) } & \multicolumn{2}{|c|}{$\begin{array}{c}\text { Nutrient } \\
(\mathrm{mg} / \mathrm{kg} \text { of } \mathrm{DM})\end{array}$} \\
\hline & & $\mathrm{CP}$ & Starch & $\mathrm{NDF}$ & $\mathrm{ADF}$ & ADL & $\mathrm{Ca}$ & $\mathrm{K}$ & $\mathrm{Mg}$ & $\mathrm{Al}$ & $\mathrm{Fe}$ \\
\hline \multicolumn{12}{|l|}{ Omasal content } \\
\hline Dry cow & Mixed ration 6 & 17.6 & 0.9 & 36.9 & 19.8 & 8.70 & 0.52 & 3.90 & 0.27 & 1,515 & 935 \\
\hline Dry cow & Grass hay only & 14.2 & 0.9 & 44.2 & 25.2 & 12.0 & 0.65 & 8.90 & 0.28 & 521 & 359 \\
\hline Lactating cow & Mixed ration 1 & 31.9 & 1.9 & 49.3 & 28.3 & 13.4 & 1.02 & 3.24 & 0.37 & 441 & 538 \\
\hline Lactating cow & Mixed ration 2 & 29.3 & 1.4 & 55.8 & 30.3 & 18.3 & 0.80 & 2.37 & 0.41 & 316 & 467 \\
\hline Lactating cow & Mixed ration 3 & 22.6 & 1.0 & 36.7 & 19.7 & 9.40 & 1.02 & 3.11 & 0.42 & 233 & 362 \\
\hline \multicolumn{12}{|l|}{ Feces } \\
\hline Heifer & Mixed ration 4 & 19.3 & 5.8 & 41.6 & 22.6 & 6.09 & 1.42 & 1.43 & 0.80 & 714 & 808 \\
\hline Heifer & Mixed ration 5 & 15.2 & 16.4 & 51.5 & 32.2 & 6.84 & 0.89 & 1.30 & 0.56 & 468 & 701 \\
\hline Dry cow & Mixed ration 6 & 15.8 & 1.1 & 59.6 & 33.3 & 9.89 & 1.69 & 1.23 & 0.67 & 1,902 & 1,608 \\
\hline Dry cow & Grass hay only & 11.2 & 0.7 & 59.3 & 35.7 & 18.1 & 1.06 & 0.85 & 0.46 & 952 & 776 \\
\hline Lactating cow & Mixed ration 1 & 16.7 & 1.2 & 50.6 & 27.9 & 8.47 & 2.28 & 0.80 & 0.66 & 946 & 1,340 \\
\hline Lactating cow & Mixed ration 2 & 17.5 & 9.7 & 54.7 & 31.4 & 7.60 & 2.14 & 0.68 & 0.71 & 743 & 1,110 \\
\hline Lactating cow & Mixed ration 3 & 16.5 & 1.4 & 53.5 & 30.7 & 7.78 & 2.33 & 0.71 & 0.84 & 492 & 903 \\
\hline
\end{tabular}

${ }^{1}$ Diets are described in Tables 1 and 2. 
Table 4. Total P content and P extraction efficiency of feed, digesta, and feces samples with HCl, NaOH-EDTA, and sequential extraction

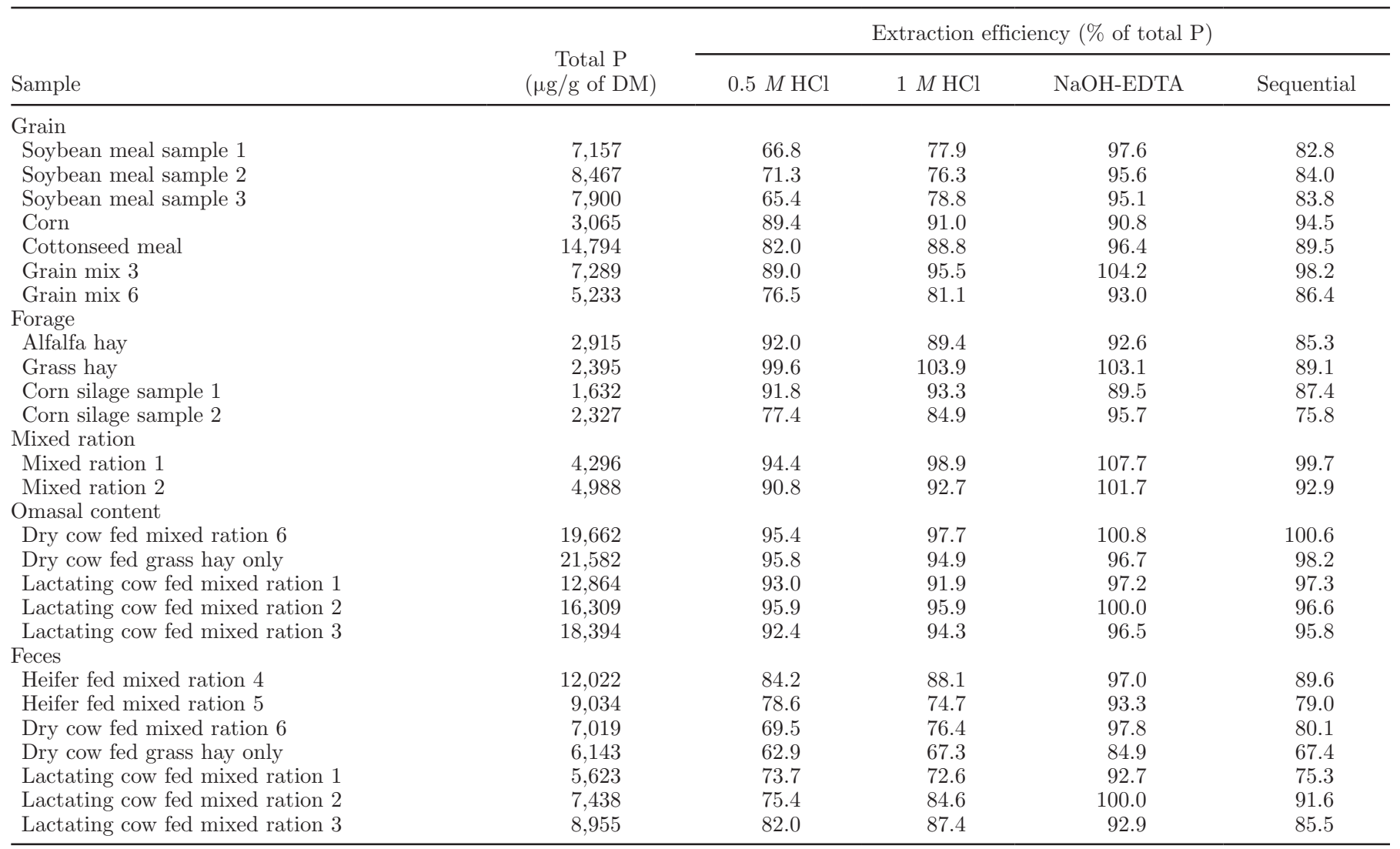

extractants are $\mathrm{HCl}$ and $\mathrm{NaOH}-\mathrm{EDTA}$, respectively, and water and $\mathrm{NaHCO}_{3}$ are often added for sequential extraction procedures (Dou et al., 2000). Little direct comparison of different extractants used individually to extract total $\mathrm{P}$ in feed, digesta, and fecal samples from dairy cows has been reported. In a recent study, McDowell et al. (2008) used acid and alkaline extractants (0.012 $M \mathrm{HCl}$ and $0.25 M \mathrm{NaOH}-0.05 M$ EDTA) to extract $\mathrm{P}$ from feces of dairy cows and observed higher total $\mathrm{P}$ recovery in alkaline extracts than in $\mathrm{HCl}$ extracts.
Effectiveness of Acid Extraction in Different Types of Samples. Acid extraction was highly effective for omasal samples (Table 5) because of the dominance of salivary (inorganic) $\mathrm{P}$ in that sample type. In contrast, $\mathrm{HCl}$ extracted only 75 to $79 \%$ of the $\mathrm{P}$ in feces, similar to the 61 to $86 \%$ of total $\mathrm{P}$ extracted from dairy fecal samples with dilute $\mathrm{HCl}(0.012 M)$ by McDowell et al. (2008). With repeated extractions of dairy feces with $1 \mathrm{M} \mathrm{HCl} \mathrm{recovery} \mathrm{of} \mathrm{P}$ was maximized at $90 \%$ (Dou et al., 2000). In the current study, the 2 concentrations of $\mathrm{HCl}(0.5$ and $1 M)$ were equally

Table 5. Phosphorus extraction efficiency from 4 classes of feeds with $\mathrm{HCl}$, NaOH-EDTA, and sequential extraction

\begin{tabular}{|c|c|c|c|c|}
\hline \multirow[b]{2}{*}{ Feed class $^{1}$} & \multicolumn{4}{|c|}{ Extraction efficiency ( $\%$ of total P) } \\
\hline & $0.5 \mathrm{M} \mathrm{HCl}$ & $1 M \mathrm{HCl}$ & $\mathrm{NaOH}-\mathrm{EDTA}$ & Sequential \\
\hline Grains and mixed rations & $80.6 \pm 0.92^{\mathrm{gf}}$ & $86.8 \pm 0.92^{\mathrm{de}}$ & $98.1 \pm 0.93^{\mathrm{a}}$ & $93.3 \pm 0.95^{\mathrm{ab}}$ \\
\hline Forages & $90.2 \pm 1.38^{\mathrm{bcd}}$ & $93.2 \pm 1.41^{\mathrm{abc}}$ & $95.2 \pm 1.38^{\mathrm{ab}}$ & $87.14 \pm 1.41^{\text {cde }}$ \\
\hline Omasal contents & $94.5 \pm 1.23^{\mathrm{ab}}$ & $95.0 \pm 1.23^{\mathrm{ab}}$ & $98.2 \pm 1.23^{\mathrm{a}}$ & $98.6 \pm 1.23^{\mathrm{a}}$ \\
\hline Dry feces & $75.2 \pm 1.05^{\mathrm{h}}$ & $78.7 \pm 1.04^{\mathrm{gh}}$ & $94.1 \pm 1.04^{\mathrm{ab}}$ & $84.1 \pm 1.04^{\mathrm{ef}}$ \\
\hline
\end{tabular}


effective in omasal samples and equally ineffective in feces (Table 5). The $\mathrm{HCl}$ extractant was more effective in feed samples than in fecal samples, perhaps because $\mathrm{P}$ is mostly present as salts of $\mathrm{K}, \mathrm{Mg}$, and $\mathrm{Ca}$ in feed samples but is present also as $\mathrm{P}$ complexed with $\mathrm{Al}$ and $\mathrm{Fe}$ in feces (McDowell et al. 2008). Hydrochloric acid extractable $\mathrm{P}$ is thought to be associated with $\mathrm{Ca}$, whereas $\mathrm{NaOH}$-EDTA-extractable $\mathrm{P}$ is considered to be associated with $\mathrm{Al}$ and Fe (McDowell and Stewart, 2005). Our observation of greater recovery of total $P$ from feces in alkaline extracts than in acid extracts (discussed below) would support this hypothesis. Within feed samples, the $\mathrm{HCl}$ extraction was more effective in forage samples (average 90.2\%) than in grains and TMR (average 80.6\%). In most studies, $1 \mathrm{M} \mathrm{HCl}$ is used as a step of sequential extraction of total $\mathrm{P}$, and the $0.5 \mathrm{M}$ concentration is used for phytate quantification studies using HPIC.

Effectiveness of Alkaline Extraction in Different Samples. The 0.25 M NaOH-0.05 $M$ EDTA extractant extracted almost all P from feces $(94.1 \%$ of total P; Table 5), as has been reported by others (Toor et al., 2005; McDowell et al., 2008). The efficiency of extraction of $\mathrm{P}$ from feeds with the alkaline extractant was also essentially complete (95.2\% for forage; $98.1 \%$ for grains and TMR) and higher than reported by McDowell et al. (2008; $60-87 \%$ recovery of total $\mathrm{P}$ in extracts of grain, forage, and TMR).

Polyvalent cations in the sample affect $\mathrm{P}$ extraction efficiency and should be considered when choosing the extractant. The Ca content of feeds may challenge alkaline extraction (Chapuis-Lardy et al., 2004; McDowell et al., 2008) because $\mathrm{NaOH}$ is less efficient in extracting $\mathrm{Ca}$ than is $\mathrm{HCl}$ and $\mathrm{Ca}-\mathrm{P}$ complexes influence the solubility of P (Turner and Leytem, 2004; Ajiboye et al., 2007). Likewise, the $\mathrm{Al}$ and $\mathrm{Fe}$ content of feces affects recovery of $\mathrm{P}$ with alkaline extraction. The use of EDTA to chelate the polyvalent cations can help resolve these problems. In cattle manure, improved recovery of total $\mathrm{P}$ was reported with the use of $\mathrm{NaOH}-$ EDTA instead of $\mathrm{NaOH}$ alone (80 vs. 32\%; Turner, 2004). Very low recovery of total $\mathrm{P}$ in $0.25 \mathrm{M} \mathrm{NaOH}-$ $0.05 M$ EDTA extract of cattle feces was reported by McDowell and Stewart (2005); this poor recovery was attributed to high concentrations of $\mathrm{Al}$ and $\mathrm{Fe}$ in their samples $(8,500$ and $4,300 \mathrm{mg} / \mathrm{kg}$ of DM, respectively): so high that these minerals could not be fully chelated by EDTA. Samples in the current study were comparatively low in $\mathrm{Al}$ and $\mathrm{Fe}(888$ and $1,035 \mathrm{mg} / \mathrm{kg}$ of DM, respectively; Tables 2 and 3 ).

Sequential Extraction. For both feed and fecal samples, lower P extraction efficiency was observed with sequential extraction than with alkaline extraction (0.25 M NaOH-0.05 $M$ EDTA) alone (Table 5). Sequential extraction (acid followed by alkaline, with or without water and $\mathrm{NaHCO}_{3}$ ) is the most common approach to fractionating $\mathrm{P}$ forms in soil, animal manure, and other organic amendments when the research purpose is to address the issue of environmental pollution from P runoff (Sharpley and Moyer, 2000; Hansen et al., 2004; McDowell and Stewart, 2005). In this study, we used $\mathrm{HCl}$ extraction, followed by $\mathrm{NaOH}-\mathrm{EDTA}$ extraction as the sequential extraction scheme and omitted the $\mathrm{H}_{2} \mathrm{O}$ and $\mathrm{NaHCO}_{3}$ steps because our interest was to select the best 2 extractants for complete recovery of total $\mathrm{P}$ rather than identifying different fractions of $\mathrm{P}$.

\section{Effect of Drying Fecal Samples on Extraction Efficiency}

Drying did not affect the efficiency of $\mathrm{P}$ extraction from feces (Table 6). The variability in extraction efficiency within extractant was higher in wet feces compared with dry feces, possibly due to the errors inherent in mixing and weighing wet fecal samples. Also, the interaction of the extractant and sample matrix may differ between dry and wet samples.

In most studies, observed changes with drying are usually transformation between different $\mathrm{P}$ forms rather than changes in total extractable P. For instance, McDowell et al. (2008) did not find any significant effect of drying on total $\mathrm{P}$ recovery from dairy feces but reported increased molybdate-reactive P (mostly inorganic phosphate) in NaOH-EDTA extracts of dry feces relative to wet feces; the opposite was observed in water extracts. Ethylenediaminetetraacetate nullifies any effect of drying on total $\mathrm{P}$ extractability because it acts as a chelating agent on humic compounds. In contrast, McDowell and Stewart (2005) observed that, when used as a step of sequential extraction, $\mathrm{NaOH}$

Table 6. Effect of drying on extraction efficiency of total $\mathrm{P}$ in feces

\begin{tabular}{lcccc}
\hline & \multicolumn{4}{c}{ Extraction efficiency $(\%$ total P) } \\
\cline { 2 - 5 } Feces group & $0.5 \mathrm{M} \mathrm{HCl}$ & $1 \mathrm{M} \mathrm{HCl}$ & NaOH-EDTA & Sequential \\
\hline Dry feces & $75.2 \pm 2.04^{\mathrm{d}}$ & $78.7 \pm 2.01^{\mathrm{cd}}$ & $94.1 \pm 2.01^{\mathrm{a}}$ & $84.1 \pm 2.01^{\mathrm{bc}}$ \\
Wet feces & $72.4 \pm 2.04^{\mathrm{d}}$ & $80.3 \pm 2.03^{\mathrm{cd}}$ & $90.1 \pm 2.01^{\mathrm{ab}}$ & $91.1 \pm 2.7^{\mathrm{ab}}$ \\
\hline
\end{tabular}

${ }^{\mathrm{a}-\mathrm{d}}$ Values with different superscripts are significantly different $(P<0.05)$. 
Table 7. Hydrochloric acid $(0.5 M)$ - and $0.25 M$ NaOH-0.05 $M$ EDTA-extractable phytate $\mathrm{P}$ in feed samples ${ }^{1}$

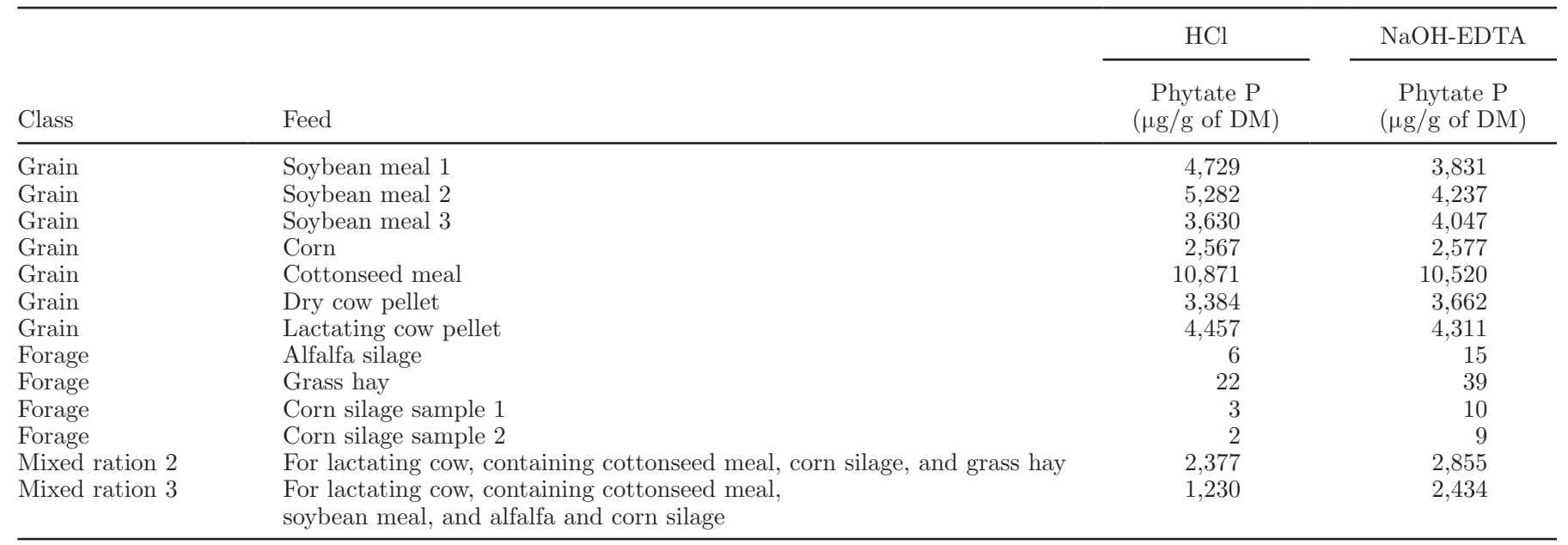

${ }^{1}$ Diets are described in Tables 1 and 2 .

recovered less total $\mathrm{P}$ from dry cattle feces than from fresh feces, probably because of increased hydrophobicity as a result of rearrangement of humic compounds. Chapuis-Lardy et al. (2004) observed that oven drying at $65^{\circ} \mathrm{C}$ reduced water-extractable inorganic P. Due to the inconsistent pattern of extraction efficiency in dry and wet feces for different extractants and the difficulty in storing wet feces, most studies use dry feces for convenience and decreased variation. Our results support that preference.

\section{Phytate Analysis by HPIC}

Based on the total $\mathrm{P}$ recovery data 2 extractants, 0.5 $M \mathrm{HCl}$ and $0.25 M \mathrm{NaOH}-0.05 M$ EDTA, were selected for phytate quantification. The NaOH-EDTA extraction was chosen because it yielded almost complete recovery of total $\mathrm{P}$ and the $0.5 \mathrm{M} \mathrm{HCl}$ extraction was used to reflect easily soluble $\mathrm{P}$, likely available for absorption by the animal. Given the lack of improvement in total $\mathrm{P}$ recovery with sequential extraction and the increased opportunity for analytical error, sequential extraction was not explored further.

Phytate concentration in $\mathrm{HCl}$ and $\mathrm{NaOH}-\mathrm{EDTA}$ extracts of feed ranged from $<5$ to $10-11,000 \mu \mathrm{g} / \mathrm{g}$ of DM (Table 7 ), with values similar to previously reported for comparable human foods and livestock feeds (Eeckhout and De Paepe, 1994; Talamond et al., 2000; McDowell et al., 2008). Phytate was also detectable in $\mathrm{HCl}$ and $\mathrm{NaOH}-\mathrm{EDTA}$ extracts of omasal and fecal samples but

Table 8. Hydrochloric acid $(0.5 M)$ - and $0.25 M$ NaOH-0.05 $M$ EDTA-extractable phytate $\mathrm{P}$ in digesta and feces samples

\begin{tabular}{|c|c|c|c|}
\hline & & $\mathrm{HCl}$ & $\mathrm{NaOH}-\mathrm{EDTA}$ \\
\hline Sample type & Diet & $\begin{array}{c}\text { Phytate } \mathrm{P} \\
(\mu \mathrm{g} / \mathrm{g} \text { of } \mathrm{DM})\end{array}$ & $\begin{array}{c}\text { Phytate P } \\
(\mu \mathrm{g} / \mathrm{g} \text { of } \mathrm{DM})\end{array}$ \\
\hline \multicolumn{4}{|l|}{ Omasal content } \\
\hline Dry cow & Mixed ration 6 & 80 & 103 \\
\hline Dry cow & Grass hay only & 11 & 5 \\
\hline Lactating cow & Mixed ration 1 & $\mathrm{ND}^{2}$ & ND \\
\hline Lactating cow & Mixed ration 2 & 3 & 7 \\
\hline Lactating cow & Mixed ration 3 & 31 & 48 \\
\hline \multicolumn{4}{|l|}{ Feces } \\
\hline Heifer & Mixed ration 4 & 176 & 231 \\
\hline Heifer & Mixed ration 5 & 270 & 369 \\
\hline Dry cow & Mixed ration 6 & 65 & 138 \\
\hline Dry cow & Grass hay only & 39 & 68 \\
\hline Lactating cow & Mixed ration 1 & 57 & 95 \\
\hline Lactating cow & Mixed ration 2 & 167 & 196 \\
\hline Lactating cow & Mixed ration 3 & 237 & 324 \\
\hline
\end{tabular}


Table 9. Effect of extraction and extract clean up on the recovery of phytate spiked to samples $^{1}$

\begin{tabular}{lcc}
\hline & \multicolumn{2}{c}{$\begin{array}{c}\text { Phytate recovery (\% } \\
\text { of quantity spiked) }\end{array}$} \\
\cline { 2 - 3 } Sample & $\mathrm{HCl}$ & NaOH-EDTA \\
\hline Alfalfa silage & 29.7 & 88.0 \\
Omasal content & & \\
$\quad$ Mixed ration 2 fed lactating cow & 42.8 & 87.5 \\
$\quad$ Mixed ration 3 fed lactating cow & 97.2 & 90.4 \\
Feces & & \\
$\quad$ Mixed ration 5 fed heifer & 81.5 & 105.5 \\
Mixed ration 3 fed lactating cow & 85.0 & 100.2 \\
\hline
\end{tabular}

${ }^{1}$ Diets are described in Tables 1 and 2 .

at lower concentrations ( $<5$ to $80-100 \mu \mathrm{g} / \mathrm{g}$ of DM and $<50$ to $<400 \mu \mathrm{g} / \mathrm{g}$ of DM respectively; Table 8).

Spike Recovery. In the spike recovery tests, the recovery of added phytate from spiked samples was almost complete with $0.25 M \mathrm{NaOH}-0.05 M$ EDTA extraction (88-106\% of spiked phytate; Table 9). Recovery of spiked phytate was not complete in many samples with $\mathrm{HCl}$ extraction. Poor recovery of spiked phytate with $\mathrm{HCl}$ extraction was observed primarily with low-phytate samples, likely due to a complex interaction among phytate, extractant, and sample matrix. Complete recovery (95-105\% of spiked phytate) of phytate spiked to food samples was reported with $\mathrm{HCl}$ extraction and HPIC analysis (Skoglund et al., 1997; Brooks and Lampi, 2001; Chen, 2004), although in those studies, inositol hexaphosphate (IP6) spikes were added after extraction, so evaluated just analytical efficiency rather than extraction efficiency. The current study used preextraction spikes (spikes added to dried ground samples before extraction). The full recovery of phytate spiked to samples preextraction suggests both the absence of any adverse effect of the alkaline extraction on phytate and also the applicability of $0.25 \mathrm{M}$ $\mathrm{NaOH}-0.05 M$ EDTA extraction for phytate quantification using HPIC.

Utility of HPIC Versus NMR. High-performance ion chromatography and HPLC have previously been used to quantify phytate in monogastric feces and digesta (Leytem et al., 2008), although NMR analysis is sometimes used. Leytem et al. (2008) found HPLC (acid extraction) to yield comparable results to NMR (alkaline extraction) when quantifying IP6 in broiler ileal digesta. For ruminant feces, ${ }^{31} \mathrm{P}$ NMR is typically used to analyze NaOH-EDTA extracts for various Pcontaining compounds (McDowell and Stewart, 2005; Toor et al., 2005; McDowell et al., 2008). McDowell et al. (2008) used $0.012 \mathrm{M} \mathrm{HCl}$ as extractant in feed and feces from dairy cows before ${ }^{31} \mathrm{P}$ NMR analysis, but mandatory $\mathrm{pH}$ adjustment to an alkaline $\mathrm{pH}$ before
NMR analysis caused precipitation of certain $\mathrm{P}$ fractions with polyvalent cations, leading to underestimation of some $\mathrm{P}$ forms.

Although ${ }^{31} \mathrm{P}$ NMR provides a full spectrum of different $\mathrm{P}$ forms in 1 run with just a single extraction, this technique is relatively insensitive and more expensive than HPLC or HPIC. Another disadvantage of NMR is that identification of inositol phosphates is difficult due to poor resolution in the orthophosphate monoester region of NMR spectra; this compromises the separation of inositol phosphate esters from other orthophosphate monoesters, leading to overestimation of IP6. This problem can be overcome by using deconvolution software but this requires considerable expertise. Due to its greater sensitivity, relative simplicity, and lower cost, HPIC is preferred over ${ }^{31} \mathrm{P}$ NMR for quantification of different $\mathrm{P}$ forms in a wide range of samples.

Special Problems with Soybean Meal. Although $\mathrm{NaOH}-\mathrm{EDT}$ was at least as effective as $0.5 \mathrm{M} \mathrm{HCl}$ in extracting phytate from most samples, soybean meal (SBM) appears to pose a special problem (Table 7). When quantified using HPIC, the phytate concentration in NaOH-EDTA extracts of SBM samples was lower than in $\mathrm{HCl}$ extracts. This may be attributed to the acidification of $0.25 M \mathrm{NaOH}-0.05 M$ EDTA extracts before chromatographic analysis rather than to inefficiencies of the alkaline extraction per se. Acidification of alkaline extracts is necessary to make extracted samples compatible with chromatographic analysis, but in SBM it may cause the formation of insoluble complexes between phytate and polyvalent cations or soy proteins, or both. We speculate that the $\mathrm{NaOH}-\mathrm{EDTA}$ extractant releases protein not only from phytate-protein complexes in the sample but also from complexes of protein with other nonphytate compounds. Also the alkaline extract would theoretically be able to interrupt metal-ligand coordination within proteins and break their $\mathrm{H}$ bonds and physical molecular forces, possibly even covalent bonds. To the eye, the supernatant of the alkaline extracts were obviously not true solutions with simple salts but instead contained colloids. When the alkaline extracts of SBM were acidified in preparation for HPIC, the protonated $\left(\mathrm{H}^{+}\right)$sites on proteins in the extract likely formed insoluble complexes with the (negatively charged) phytate in the extract. Precipitate was visually obvious in the alkaline extracts following acidification and we hypothesize that the precipitate comprised insoluble protein-phytate complexes, removing phytate from the solution.

This is a problem specific to SBM because, in soy, more phytate is associated with protein than with $\mathrm{Ca}$ and Mg (Brooks and Morr, 1982). Tzeng et al. (1990) reported that proteins and metal ions compete with 
each other to form complexes with phytic acid in acidic media. Hartman (1979) reported that in $\mathrm{pH}$ range of 2 to 4.5, phytate removal from SBM extract was inefficient due to strong phytate-protein complexes; phytate can be displaced from this complex only in the presence of excess divalent cations.

Thus, the apparently low recovery of phytate from SBM with alkaline extraction in our study was likely due to problems imposed with the acidification step of the postextraction treatment. Therefore, although it gave incomplete recovery of total $\mathrm{P}$ (Tables 4 and 5), we conclude that $\mathrm{HCl}$ extraction is still preferred for SBM samples unless alkaline extracts can be made compatible with HPIC in some way other than acidifying the extract. More research is needed with other high-protein feeds to evaluate this hypothesis.

\section{CONCLUSIONS}

A method is described for analysis of phytate in ruminant digesta and fecal samples consisting of extraction of samples, extract clean up, and HPIC analysis. Alkaline extraction was able to extract $\mathrm{P}$ almost completely from all sample types; acid extraction was adequate for feeds and omasal samples but not for feces. The described extract clean-up procedures successfully removed the interference from sample matrix, allowing accurate measurement of low concentrations of phytate in fecal and digesta samples from dairy cattle with HPIC. Soy samples may pose special problems when alkaline extracted because of protein-phytate interactions in the extract. The described method combines the extraction power of $\mathrm{NaOH}-\mathrm{EDTA}$ with the precision and sensitivity of HPIC quantification to measure phytate in feeds, ruminant digesta, and feces. This method is simple, rapid, accurate, and robust and may help advance knowledge of dynamics of digestion of phytate and $\mathrm{P}$ in ruminants.

\section{REFERENCES}

Ajiboye, B., O. O. Akinremi, Y. Hu, and D. N. Flaten. 2007. Phosphorus speciation of sequential extracts of organic amendments using nuclear magnetic resonance and X-ray absorption near-edge structure spectroscopies. J. Environ. Qual. 36:1563-1576.

AOAC. 1984. Official Methods of Analysis. 14th ed. Association of Official Analytical Chemists. Washington, DC.

Bourdillon, J. 1951. A crystalline bean seed protein in combination with phytic acid. J. Biol. Chem. 189:65-72.

Bravo, D., F. Meschy, C. Bogaert, and D. Sauvant. 2003. Phosphorus availability of oilseed meals determined by the apparent faecal digestibility technique. Anim. Feed Sci. Technol. 108:43-60.

Brooks, J. R., and C. V. Morr. 1982. Phytate removal from soy protein isolates using ion exchange processing treatments. J. Food Sci. 47:1280-1282.
Brooks, S. P. J., and B. J. Lampi. 2001. Problems associated with measuring phytate in infant cereals. J. Agric. Food Chem. 49:564-569.

Chapuis-Lardy, L., J. Fiorini, J. Toth, and Z. Dou. 2004. Phosphorus concentration and solubility in dairy feces: Variability and affecting factors. J. Dairy Sci. 87:4334-4341.

Chen, Q. 2004. Determination of phytic acid and inositol pentakisphosphates in foods by high-performance ion chromatography. J. Agric. Food Chem. 52:4604-4613.

Cherry, N. M., B. D. Lambert, and J. P. Muir. 2010. Ruminal and total tract phosphorus release from feedstuffs in cattle measured using the mobile nylon bag technique. J. Anim. Physiol. Anim. Nutr. (Berl.) 94:665-669.

Clark, W. D. Jr., J. E. Wohlt, R. L. Gilbreath, and P. K. Zajac. 1986. Phytate phosphorus intake and disappearance in the gastrointestinal tract of high producing dairy cows. J. Dairy Sci. 69:3151-3155.

Dou, Z., J. D. Ferguson, J. Fiorini, J. D. Toth, S. M. Alexander, L. E. Chase, C. M. Ryan, K. F. Knowlton, R. A. Kohn, A. B. Peterson, J. T. Sims, and Z. Wu. 2003. Phosphorus feeding levels and critical control points on dairy farms. J. Dairy Sci. 86:3787-3795.

Dou, Z., J. D. Toth, D. T. Galligan, C. F. Ramberg Jr., and J. D. Ferguson. 2000. Laboratory procedures for characterizing manure phosphorus. J. Environ. Qual. 29:508-514.

Eeckhout, W., and M. De Paepe. 1994. Total phosphorus, phytatephosphorus and phytase activity in plant feedstuffs. Anim. Feed Sci. Technol. 47:19-29.

Fontaine, T. D., W. A. Pons, and G. W. Irving. 1946. Protein-phytic acid relationship in peanuts and cottonseed. J. Biol. Chem. 164:487-507.

Hall, M. B. 2009. Determination of starch, including maltooligosaccharides, in animal feeds: Comparison of methods and a method recommended for AOAC collaborative study. J. AOAC Int. 92:42-49.

Hansen, J. C., B. J. Cade-Menun, and D. G. Strawn. 2004. Phosphorus speciation in manure-amended alkaline soils. J. Environ. Qual. 33:1521-1527.

Hartman, G. H. Jr. 1979. Removal of phytate from soy protein. J. Am. Oil Chem. Soc. 56:731-735.

He, Z., C. W. Honeycutt, T. S. Griffin, B. J. Cade-Menun, P. J. Pellechia, and Z. Dou. 2009. Phosphorus forms in conventional and organic dairy manure identified by solution and solid state P-31 NMR spectroscopy. J. Environ. Qual. 38:1909-1918.

Huhtanen, P., P. G. Brotz, and L. D. Satter. 1997. Omasal sampling technique for assessing fermentative digestion in the forestomach of dairy cows. J. Anim. Sci. 75:1380-1392.

Kincaid, R. L., D. K. Garikipati, T. D. Nennich, and J. H. Harrison. 2005. Effect of grain source and exogenous phytase on phosphorus digestibility in dairy cows. J. Dairy Sci. 88:2893-2902.

Knowlton, K. F., J. S. Radcliffe, C. L. Novak, and D. A. Emmerson. 2004. Animal management to reduce phosphorus losses to the environment. J. Anim. Sci. 82(E-Suppl.):E173-E195.

Leytem, A. B., P. Kwanyuen, P. W. Plumstead, R. O. Maguire, and J. Brake. 2008. Evaluation of phosphorus characterization in broiler ileal digesta, manure, and litter samples: ${ }^{31} \mathrm{P}-\mathrm{NMR}$ vs. HPLC. J. Environ. Qual. 37:494-500.

Lin, L., I. Ockenden, and J. N. A. Lott. 2005. The concentrations and distribution of phytic acid-phosphorus and other mineral nutrients in wild-type and low phytic acid 1-1 (lpa1-1) corn (Zea mays L.) grains and grain parts. Can. J. Bot. 83:131-141.

McDowell, R. W., Z. Dou, J. D. Toth, B. J. Cade-Menun, P. J. A. Kleinman, K. Soder, and L. Saporito. 2008. A comparison of phosphorus speciation and potential bioavailability in feed and feces of different dairy herds using ${ }^{31} \mathrm{P}$ nuclear magnetic resonance spectroscopy. J. Environ. Qual. 37:741-752.

McDowell, R. W., and I. Stewart. 2005. Phosphorus in fresh and dry dung of grazing dairy cattle, deer, and sheep: Sequential fraction and phosphorus-31 nuclear magnetic resonance analyses. J. Environ. Qual. 34:598-607. 
Mjoun, K., K. F. Kalscheur, A. R. Hippen, and D. J. Schingoethe. 2008. Ruminal phosphorus disappearance from corn and soybean feedstuffs. J. Dairy Sci. 91:3938-3946.

Morse, D., H. H. Head, and C. J. Wilcox. 1992. Disappearance of phosphorus in phytate from concentrates in vitro and from rations fed to lactating dairy cows. J. Dairy Sci. 75:1979-1986.

Nelson, T. S., L. B. Daniels, J. R. Hall, and L. G. Shields. 1976. Hydrolysis of natural phytate phosphorus in the digestive tract of calves. J. Anim. Sci. 42:1509-1512.

NRC. 2001. Nutrient Requirements of Dairy Cattle. 7th rev. ed. Natl. Acad. Sci., Washington, DC.

Park, W.-Y., T. Matsui, C. Konishi, S.-W. Kim, F. Yano, and H. Yano. 1999. Formaldehyde treatment suppresses ruminal degradation of phytate in soyabean meal and rapeseed meal. Br. J. Nutr. 81:467-471.

Phipps, R. H., J. D. Sutton, D. E. Beever, and A. K. Jones. 2000. The effect of crop maturity on the nutritional value of maize silage for lactating dairy cows 3. Food intake and milk production. Anim. Sci. 71:401-409.

Puggaard, L., N. B. Kristensen, and J. Sehested. 2011. Effect of decreasing dietary phosphorus supply on net recycling of inorganic phosphate in lactating dairy cows. J. Dairy Sci. 94:1420-1429.

Ravindran, V., G. Ravindran, and S. Sivalogan. 1994. Total and phytate phosphorus contents of various foods and feedstuffs of plantorigin. Food Chem. 50:133-136.

SAS Institute. 2002. SAS User's Guide: Statistics. Version 9.2. SAS Inst. Inc., Cary, NC.

Sharpley, A., and B. Moyer. 2000. Phosphorus forms in manure and compost and their release during rainfall. J. Environ. Qual. 29:1462-1469.

Skoglund, E., N.-G. Carlsson, and A.-S. Sandberg. 1997. Determination of isomers of inositol mono- to hexaphosphates in selected foods and intestinal contents using high-performance ion chromatography. J. Agric. Food Chem. 45:431-436.
Talamond, P., S. Doulbeau, I. Rochette, J.-P. Guyot, and S. Treche. 2000. Anion-exchange high-performance liquid chromatography with conductivity detection for the analysis of phytic acid in food. J. Chromatogr. A 871:7-12.

Toor, G. S., B. J. Cade-Menun, and J. T. Sims. 2005. Establishing a linkage between phosphorus forms in dairy diets, feces, and manures. J. Environ. Qual. 34:1380-1391.

Turner, B. L. 2004. Optimizing phosphorus characterization in animal manures by solution phosphorus-31 nuclear magnetic resonance spectroscopy. J. Environ. Qual. 33:757-766.

Turner, B. L., and A. B. Leytem. 2004. Phosphorus compounds in sequential extracts of animal manures: Chemical speciation and a novel fractionation procedure. Environ. Sci. Technol. 38:61016108

Turner, B. L., M. J. Papházy, P. M. Haygarth, and I. D. McKelvie. 2002. Inositol phosphates in the environment. Philos. Trans. R. Soc. Lond. B Biol. Sci. 357:449-469.

Tzeng, Y.-M., L. L. Diosady, and L. J. Rubin. 1990. Production of canola protein materials by alkaline extraction, precipitation, and membrane processing. J. Food Sci. 55:1147-1151.

Valk, H., L. B. J. Šebek, and A. C. Beynen. 2002. Influence of phosphorus intake on excretion and blood plasma and saliva concentrations of phosphorus in dairy cows. J. Dairy Sci. 85:2642-2649.

Van Soest, P. J., J. B. Robertson, and B. A. Lewis. 1991. Methods for dietary fiber, neutral detergent fiber, and nonstarch polysaccharides in relation to animal nutrition. J. Dairy Sci. 74:3583-3597.

VandeHaar, M. J., and N. St-Pierre. 2006. Major advances in nutrition: Relevance to the sustainability of the dairy industry. J. Dairy Sci. 89:1280-1291.

Wheeler, E. L., and R. E. Ferrel. 1971. A method for phytic acid determination in wheat and wheat fraction. Cereal Chem. 48:312-316. 